\title{
LABOR MARKET INSERTION OF PROFESSIONAL VENEZUELAN IMMIGRANTS IN NORTHERN CHILE: PRECARIOUSNESS AND DISCRIMINATION IN THE LIGHT OF MIGRATION POLICY
}

\author{
Inserção no mercado de trabalho de migrantes qualificados \\ venezuelanos no norte do Chile: precariedade e discriminação \\ à luz da política de migrações
}

José Berríos-Riquelme*

\begin{abstract}
This article describes the labor market insertion experiences of a group of professional Venezuelan immigrants in northern Chile. Using a qualitative methodology, fourteen people who met the inclusion criteria were interviewed. The participants' discourses show that their experiences have been stressful because they have not been able to revalidate their degrees, have to take on jobs for which they are overqualified, and suffer exploitation and discrimination. The stories are analyzed based on previous studies and related theory, finding that the main factor affecting this reality is the current Chilean immigration legislation, which has an orientation based on control and national security. It is concluded that the current immigration legislation facilitates immigrants' labor precariousness and contributes to their situation of vulnerability.
\end{abstract}

Keywords: highly skilled immigrants; south-south migration; public policies; migration law.

Resumo. Este artigo descreve as experiências de inserção no mercado de trabalho de um grupo de imigrantes venezuelanos qualificados profissionalmente no norte do Chile. Os relatos dos participantes revelam que suas experiências têm sido estressantes por não poderem revalidar seus diplomas, tendo que assumir empregos para os quais são super qualificados e sofrem exploração e discriminação. As histórias foram analisadas com base em estudos anteriores e teorias relacionadas, encontrando como principal fator que afeta esta realidade a legislação de imigração chilena, que possui uma orientação baseada no controle e segurança nacional. Conclui-se que essa política de imigração contribui para a precaridade do trabalho e a situação de vulnerabilidade enfrentada por esses imigrantes.

Palavras-chave: imigrantes altamente qualificados; migração sul-sul; políticas públicas; lei de migração.

Profesor Asistente, Departamento de Ciencias Sociales, Universidad de Tarapacá, Chile. Iquique, Chile. E-mail: jberrios@uta.cl. Orcid: https://orcid.org/0000-0003-2947-4739. 


\section{Introduction}

In the last ten years, Venezuela has suffered a crisis that has reached unprecedented characteristics in contemporary South American history. Different political and economic variables, nationally and internationally, combined and impacted Venezuelan society, which is currently suffering hyperinflation, poverty, shortages, political instability, and repression at all levels (Buxton, 2018; Pittaluga et al., 2020). This reality has led thousands of Venezuelans to leave their country, to the point that this phenomenon of human mobility is considered one of the largest exoduses of the present century (Organización Internacional de las Migraciones [OIM], 2019).

Between 2015 and 2018, three million people left Venezuela, a figure that increased to 4.5 million people by 2019 and that in total, corresponds to approximately $14 \%$ of the population of that country (Human Rights Watch [HRW], 2020). The increase in the exodus is also evident in Venezuelans' asylum applications in recent years, who currently rank third worldwide after Afghanistan and Syria (Organization for Economic Cooperation and Development [OECD], 2019).

The South American region governments showed concern in granting a humanitarian response to Venezuelan immigrants, facilitating their transit through their territories, and allowing them to regulate their migratory situation thanks to multilateral agreements such as MERCOSUR. However, the number of these people exceeded the estimates made by international organizations, leading to the fact that since 2018, several countries added additional requirements for Venezuelan nationals to enter through their borders (HRW, 2020).

Additionally to the obstacles for the entry and transit of Venezuelan immigrants, there are various restrictions imposed in South American countries to process residence permits. One example is Ecuador, which changed the requirements stipulated in its legislation to limit residence permits and, at the same time, began to request visas to those who assured that their final destination was a third country and only wanted to occupy its territory for transit (Ramírez et al., 2019). In Chile, Venezuelan immigration restrictions were established in April 2018, highlighting the creation of a "Visa of Democratic Responsibility" exclusively for Venezuelan natives, which had to be requested in one of the two consulates that Chile has in that country. This restriction was lifted in June 2019, and its processing was enabled in any Chilean consulate in the world.

The imposition of additional requirements stands as a migration selection process since only those who possess all the documents or those who meet the profile according to the border official's criteria can enter. In this line and as Stefoni et al. (2018) point out, in the Latin American concert, it has been given that migration policies have added requirements to hinder the entry of certain nationalities and condition some of their rights, thus activating mechanisms that make the conditions of insertion of these people more precarious. In the authors' 
words, these policies generate a context that favors immigrants' vulnerability, promotes precarious labor insertion, and leads the national population to see them as a threat to their labor sources.

In this line, Stefoni et al. (2019) recently found that Venezuelan immigration in Chile not only has difficulties to enter the country, but also presents problems to revalidate their degrees and access a job according to their training. According to the authors, this is due to the control policy of the State, which in addition to placing obstacles to obtaining residence permits, seeks to produce workers who are inserted in precarious systems. So far, it is not known whether this reality is transversal for all Venezuelan immigrants in Chile, since this area of study is incipient in the country. For this reason, the objective of this article is to analyze the impact of Chilean migration policy on the labor incorporation of skilled Venezuelan immigrants in the Tarapacá region.

The Tarapacá region is located in northern Chile and since its origins, it has been a magnet for immigrants due to the typical economic activities of the area, such as fishing, mining and trade, which are facilitated by having one of the main international ports in Chile (Tapia, Ramos, 2013). These characteristics are added to its cross-border position, which with its particularities, has historically been an area of entry, transit and destination for people of South American origin who yearn to find a niche to incorporate themselves laborly in Chile (Leiva et al., 2017; Tapia, 2015). Thus, the Tarapacá region presents a set of factors that make it an ideal place for immigrants of different origins to settle with some preference in the regional capital, a city called Iquique.

This manuscript has the following sections. First, the so-called Chilean migratory policy will be described, emphasizing the requirements for residence permits for the Venezuelan population and also the procedure they must follow to revalidate their university degrees. Next, the methodology used will be addressed and the main findings of the labor incorporation of the participants will be presented in discussion with the existing literature. Finally, we suggest lines for future research and conclude on the basis of the results and the literature consulted.

\section{The Chilean "migration policy" for Venezuelan immigrants}

The current Chilean migration policy is a decree-law of the Ministry of the Interior that was elaborated during the military dictatorship in 1975 and complemented by a regulation of 1984 . This decree is a regulation that seeks to regulate the entry, stay, and exit of migrants from a restrictive conception. Several studies have shown that its regulatory framework covered under the doctrine of national security, leaves immigrants in a situation of vulnerability due to the discretion it grants to the agencies in charge of applying it (Pavez-Soto, Colomés, 2018).

Since Chile returned to democracy, governments of the left and right have made different amendments to modernize some aspects of this law (Thayer, 2016). 
Although responses focused on human rights have predominated in this political governance, it is undeniable to recognize a predominance of the security approach based on population control. This migration management has favored political positions and ideological discourses against migration, which would find their reason in the law on foreigners, which constructs immigrants as economic subjects and perpetuates them as a threat to nationals (Stefoni, 2011).

Recently, in December 2020, a mixed commission of the Congress approved the new immigration law, which will provide a new framework for immigration and foreigners' affairs. However, this law is in the constitutional court, as an inapplicability request was filed to fourteen articles claimed to be contrary to the Constitution. Such as article №135, which declares the deprivation of liberty for 72 hours to a foreigner who has been decreed expellable; another example is №132, which establishes the return of unaccompanied minors to their countries. When this is resolved, the law will be enacted one year after the regulations are established. Despite the advances of this law concerning the previous one, the Chilean State's migratory outlook continues to have a strong national security orientation.

In this sense, Stefoni et al. (2018) expose that a liberal migration policy is appreciated in Chile, which stands out for maintaining a positive discourse towards migration while introducing control mechanisms covered by a national security look focused on specific groups of foreigners. An example of the above are the restrictions that were announced in April 2018, which aimed to "favor" the regularization of the country's immigrant population, even for those who entered irregularly. This package of measures also contemplated new types of residence permits and obeyed a political campaign whose slogan was "putting the house in order", which alluded to an alleged chaos and abuse towards foreigners, but what was really sought was that immigrants would have to apply for a visa before arriving in Chile.

In the case of the Venezuelan population, the "Visa of Democratic Responsibility" (VDR) was created. This visa grants a Chilean DNI for one year, after which a new regularization process must be initiated, for which a labor contract and a certificate attesting the payment of taxes are required. The demand of this requirement is not in line with the actions of President Sebastián Piñera, who later in February 2019 went to Cúcuta to deliver humanitarian aid to the Venezuelan people and at the same time, support the movement that opposes Nicolás Maduro. On occasion, Piñera stated that Chile is concerned about Venezuela and is willing to help, generating expectations to those who wanted to leave that country and were looking for a destination. This event influenced the increase of Venezuelan entries to Chile during the first half of 2019, leading the Government to start requiring a consular tourist visa for Venezuelan nationals (who did not have a VRD) to enter the country since June 2019. Among the visa requirements are a passport issued since 2013, four passport-sized photographs, a letter of invitation or hotel reservation, and proof of economic solvency. 
This last measure was implemented the same day it was announced, immediately hurting migrants and asylum seekers who wanted to enter Chile. Proof of this is the crisis that occurred at the northern border of the country between June and July 2019, where hundreds of Venezuelan families who had already started the journey and for obvious reasons had not processed their consular tourist visa, had to sleep outdoors for weeks at the Peruvian border waiting for a humanitarian response from the Chilean government (Rojas, 2019). The situation was resolved by granting authorization for some people to enter Chile; despite this, it is unknown the authorities' criterion for this "selection". This issue reaffirms the dichotomy established in Chilean migration policy discourse, advocating for human rights, but with a high sense of control and national security.

In addition to experiencing these difficulties imposed on their nationality, Venezuelan immigrants who have managed to enter Chile have also had to regularize their migratory situation. In professionals' case, this procedure is even more complicated if they wish to revalidate their degree since this procedure has a high economic cost and waiting times that usually extend beyond what is established by law.

\section{The process of degree revalidation in Chile}

Any immigrant who arrives in Chile with a professional degree and wishes to practice their profession must-revalidate their degree. Currently, there are two options in the country to carry out this procedure. The first is automatic and works for countries with an agreement with the Ministry of Foreign Affairs or the Ministry of Education. The second is for countries that do not have an agreement in force with Chile. In this case, individuals must initiate a background evaluation process at the Universidad de Chile $(\mathrm{UCH})$.

In the case of Venezuelan immigrants, their country does not have agreements in force, so they must revalidate their degree at the $\mathrm{UCH}$, an institution that for these purposes only operates in Santiago, a city that is 1,757 kilometers south of the Tarapacá region, in a trip that takes at least 22 hours by land and flights that average a value of 100 USD. To initiate this procedure, previously, all the necessary documents must have been apostilled or legalized in Venezuela, then validated at the Ministry of Foreign Affairs ${ }^{1}$, and then presented at the $\mathrm{UCH}^{2}$.

\footnotetext{
1 The Ministry of Foreign Affairs requests an Original professional degree, including the Acta de Grado, an original transcript of grades for each subject and the entire academic period, a certificate attesting to the institution's existence where the person studied and their identification, which can be a passport or Chilean identity card.

2 Universidad de Chile requests: Diploma of title or degree in original and legalized photocopies before a Chilean notary, the concentration of grades in original and photocopy legalized before a Chilean notary, Plan of Study in original and photocopy, curriculum vitae, declaration for professional practice in the country of origin (visaed by the respective consulate when deemed necessary), application form and other documents deemed pertinent.
} 
The revalidation process begins with the payment of 140 USD to enter the documents in digital format in the Prorrectoría of the $\mathrm{UCH}$; if the immigrant meets the requirements, they will be summoned in-person to bring the original documents and a legalized copy of each one before a Chilean notary. In the second step, they must pay 210 USD to the Academic Unit of the area where the study of the curriculum of their profession is derived, a stage that supposedly lasts a maximum of 2 months, but from the entrance to the result of the curricular study, it is estimated 5 months. The possible answers are a) revalidation accepted, b) revalidation denied, or c) the person will have to meet additional revalidation requirements: take exams, complete final degree activities, or take courses related to the Chilean professional degree he/she wishes to revalidate. If they must comply with these requirements, they are informed of the extra fee they must pay to take the exams, which will vary depending on the degree program. If the person abandons the process, is denied the revalidation, or resigns, they will have to wait twelve months before starting the process again. In this new opportunity, they will have to start from scratch in terms of time and associated costs.

Professionals' requirements will vary by profession and waiting time, and the tests to be taken. For example, for those who studied law, the first step is to revalidate at the $\mathrm{UCH}$ the degree of Bachelor in Legal and Social Sciences, then perform their professional practice for six months at the Judicial Assistance Corporation; once these requirements are fulfilled, they may apply for the title of attorney at the Supreme Court of Justice. On the other hand, a surgeon who revalidates his degree may only practice his profession in the private sector or apply for public positions that are not related to medicine; if he wishes to practice as a doctor in the public health system, he will have to take the Single National Examination of Knowledge in Medicine (EUNACOM). Regarding other professions, after reviewing the curricular exam, there is the option of automatic revalidation, taking a test, or taking a course; this decision will be based exclusively on the result of the study plan's evaluation.

In this line, Article 144 of the new law on foreigners states that any regional public university with five or more accreditation years may carry out the revalidation of studies. Despite the above, there are still at least two years to go before this legislation comes into force, which is why immigrants from the regions will have to continue investing time and money to travel to Santiago to carry out this procedure.

\section{Methodology}

The present investigation is a fieldwork case study with professional Venezuelan immigrants in the north of Chile. Between August and October 2019, fourteen professional Venezuelan immigrants who had been living for seven months to three years in the Tarapacá region were interviewed; all were in a legitimate situation and had thought of Chile as their final destination when they left Venezuela. At first, people were selected through convenience sampling and later using the 
snowball technique. The saturation criterion determined the number of interviews to be carried out. The inclusion criteria were: being an immigrant from Venezuela, having lived in Chile for more than six months, obtaining a professional degree in the country of origin, and the Tarapacá region being the first place of settlement in the country. The origin of the participants is from the Venezuelan States of Miranda, Carabobo, and Zulia.

Semi-structured interviews were used to determine the experience of these people. Before starting the interview, participants were explained the purpose of the study, how the information they would share would be used, and the voluntary nature of their participation. Verbal consent was requested to participate and record the study's interviews, which were registered with a cell phone and later transcribed into a Word file. No financial reward was assigned to these people. Each interview lasted between 30 and 50 minutes, which were carried out in cafeterias and fast-food outlets in the city of Iquique. Participants were assigned a fictitious name to protect their identity. Coding was done manually, then emerging categories were created, and information was analyzed using qualitative content analysis (Bryman, 2012). The characteristics of the participants are shown in Table 1.

Table 1 - Characterization of the participants

\begin{tabular}{cccccc}
\hline Participant & Gender & Age & Profession & Occupation or trade & Time in Chile \\
\hline José & M & 32 & Economist & Seller & 25 months \\
Carlos & M & 34 & Accountant & Seller & 18 months \\
Jorge & M & 25 & Lawyer & Cashier at fast food shop & 10 months \\
Fernando & M & 26 & Manager & Cook in fast food place & 7 months \\
Pablo & G & 31 & Accountant & Cook in fast food place & 12 months \\
Roberto & G & 32 & Accountant & Waiter in restaurant & 12 months \\
Lucía & F & 48 & Educator & Seller & 35 months \\
Paulina & F & 31 & Lawyer & Beauty salon & 15 months \\
Paola & F & 36 & Lawyer & Beauty salon & 15 months \\
Juan & M & 28 & Psychologist & Seller & 20 months \\
Antonia & F & 29 & Educator & Cook in fast food place & 8 months \\
Andrés & M & 34 & Professor & Cleaning in mall & 8 months \\
Ximena & L & 31 & Lawyer & Seller & 10 months \\
Marcela & L & 28 & Engineer & Seller & 10 months \\
\hline
\end{tabular}

Note. $\mathrm{M}=$ Male; $\mathrm{G}=$ Gay; $\mathrm{F}=$ Feminine; $\mathrm{L}=$ Lesbian.

Source: Own elaboration based on the interviews carried out. 


\section{Results}

The analysis reveals two broad issues in the labor market incorporation of the participants. First, there is access to low-skilled jobs due to problems in revalidating their degrees. Second, there are the experiences of discrimination in their workplaces. These issues are presented and analyzed below concerning Chilean migration policy.

\section{"I didn't expect it": problems in revalidating the degree and access to low-skilled jobs}

As described in the previous section, the complexity and economic cost of the revalidation of degrees is a problem that all professional immigrants arriving in Chile must face. In the case of immigrants living in regions, this process harms their insertion process since all procedures must be carried out in person in the city of Santiago, which means incurring costs associated with transportation and lodging. Although the process has been streamlined in recent years by accepting the application registration in digital format, the document presentation and the tests must be done in person in the city of Santiago. In this way, immigrants living in regions such as Tarapacá have to spend large sums of money to complete the process and wait several months to respond to their application.

Participants were consistent in stating that they thought it would be easy to arrive in Chile and revalidate their university degrees. The main difficulty in carrying out this procedure is the economic cost of traveling to Santiago and staying in this city for several days, which is why there is a generalized decision to postpone the procedure and prioritize the search for work to cover their basic needs, such as finding a place to live, buying food or sending money to Venezuela. In this regard, Andres points out: "[...] I cannot revalidate because my salary is enough to cover my needs for rent and expenses, but it does not allow me to save, just work, for locomotion, market, and that's it". Paola has a similar opinion about the revalidation of studies: "Well, I don't have the possibility because I don't have money, now what I earn is to cover the expenses and suddenly to buy the little things for the apartment, then one day we buy the refrigerator, we buy a chair and so on, and not to revalidate now". These stories exemplify the reasoning and actions taken by several of the participants when they were unable to revalidate their university degrees.

In the case of those who started the revalidation process from a distance, their objective has been truncated, because although they started the process thanks to the savings they brought from their country, later they could not dedicate the time to study or to carry out the requested internship, since they had to work while waiting for the result of the curricular evaluation and the deadline to take the test. For example, Paulina said: "[...] they gave me three subjects to take, they gave me a year to take the degree exam, but it has been difficult because being 
here alone, preparing for the revalidation is complicated because I have to stop working to study, I had to choose, so work or study". To prioritize work over study in order to revalidate the degree is a transversal dynamic in the people who started the process, like Jorge, who bluntly points out that he has already abandoned the idea of practicing their profession: "right now it is not in my plans; first I will find a good job". The people interviewed described the experience as discouraging and, in some cases, indicated that they have reconsidered whether it was right to leave Venezuela; however, they are willing to face the situation since they do not expect to return to their country soon.

When analyzing the pros and cons of their arrival in Chile, the immigrants realize that the only option to stabilize themselves is to be patient and live this stage with peace of mind since the revalidation of their degree will have to wait. A phrase that appears in almost all the interviews is "I did not expect it," alluding to the awareness that they will not be able to practice their profession in Chile in the short or medium term. The stories indicate that the participants assumed that this reality would last for a long time and they will have to deal with it. Appreciating an everyday discourse that has as its standard the resignation of having to look for jobs outside the area in which they were trained, as Fernando states: "[...] so, well, the first thing I have seen is that I will have to go to other aspects outside my degree to see if I can get a job".

As the participants point out, assuming this situation led them to look for jobs for which they are overqualified, given that they do not have the economic resources to revalidate their degree and the constraints linked to their subsistence. These findings are similar to those of Stefoni et al. (2019) with Venezuelan immigrants in Santiago de Chile, who argue that the difficulty in finding a job according to their training and having to access a lower-skilled job is not only related to the problems to revalidate the degree, but also because this conglomerate does not have sufficient support networks for their incorporation.

A particular characteristic that is repeated in the speeches is the difficulty for employers to hire professionals to perform jobs considered low-skilled, as Lucía points out: "many times, the employer thinks that since you are a professional, you are not capable of doing complete jobs, frying potatoes, washing dishes, doing any other activity that is not based on your profession". This situation leads some immigrants to develop strategies to find work, including deleting information from their $\mathrm{CV}$ or practically inventing one without information about their higher education, since they feel that being a qualified immigrant is a disadvantage. For example, Ximena narrates: "at least right now last I took out that I was a professional, I had to put that I did a secretarial course and that I finished it and I removed workshops, and that thing I did in college regarding law and that is the only way I have been called". 
According to the interviews, Venezuelan immigrants make a thoughtful analysis framed in the idea of adapting to the context because they see it as a momentary situation while they gather the money to revalidate their degree and work in what they were trained. In this sense, the people interviewed separate the explanations of how they get jobs and develop in this area. In this context, some stories seek to justify that these jobs are temporary, as described by Fernando: "Sometimes you have to get those jobs that are not in your area and that are mediocre salaries, but that helps you to be there in the meantime, while you can".

Although it has been difficult for the participants to take jobs for which little qualification is needed, they state that they are willing to continue in this field because of the reasons for their immigration, the need to remain in the host society, and to save for their revalidation. From a theoretical point of view, these findings align with the approach that states that immigrants assume their disadvantaged position in the host society and opt for labor strategies not to have opted in their country of origin (Castles, de Hass, Miller, 2014). In this regard, Portes (2007) points out that when professional immigrants manage to enter the labor market, the opportunities for insertion are characterized by reproducing the immigrant category's activities as segmented work.

Although there is an air of optimism among the participants for having found a job that allows them to remain in society, some interviewees cannot hide the fact that the situation has affected them and describe the context as stressful, but they know that it is the only option they have for the moment. As José points out, "[...] swimming against the current is difficult, because you have to make up your mind that you are going to do something outside the context you had in mind, so you spend a lot of energy thinking and focusing on being safe and positive". The experience of finding a job in a different area is described as a stressful process that generates a crisis in their life cycle. In this regard, Urzúa et al. (2017) point out that the South American population in Chile has precarious living conditions while getting a job, which, added to their stressful experiences, their mental health is severely affected.

The stories reveal how difficult it is to start working in Chile and, at the same time, show that Venezuelan immigrants maintain a balance between the impact of their flight from a society in conflict and the search for solutions to maintain and project themselves in Chile. Despite the above, the incorporation of Venezuelan immigrants is linked to their educational background and the context imposed by the receiving society through migration policy. As can be seen, this policy's design is intended to make it as difficult as possible to revalidate university degrees from the regions and thus promote the insertion of immigrants in segmented markets where they perform precarious jobs. 


\section{Experiences in the workplace: working hours, discrimination, and internalized threat}

The current Chilean immigration policy does not refer extensively to the labor terms for immigrants; the only important things to rescue are the number of immigrants per company and the contracts' clauses. This law stipulates that any company may have up to $15 \%$ foreigners among its workers regarding the former. Regarding the clauses added in the contract, the most important is to pay for the return of the immigrant and his family to their country of origin or a mutually agreed country and that they will not be able to start working until the visa is fully processed.

For a long time, these requirements have hindered the regularization of immigrants since it is difficult to find employers who are willing to sign a contract of this type, which is why most immigrants choose to work without documents to generate income while waiting an average of six months for their visa subject to contract to be ready. In this line, it is necessary to emphasize that this work visa only allows to work with the employer in question, so if the immigrant resigns or is fired, they will have to start the process again if they wish to enter another job. Along these lines, the reports allow us to distinguish three essential aspects. The first refers to the labor abuses they suffer from their employers. The second is the discrimination they have received in their jobs. The third is the feeling of internalized threat with which they justify why they are victims of discriminatory acts.

Regarding labor abuse, the participants indicate that their experience has been impaired because of situations categorized as abusive due to the exploitation and mistreatment received. In their speeches, it is clear that working in a job where they are overqualified does not affect them; however, the situation changes when they perceive that employers are committing "abuse". In Antonia's words: "For me there is no problem, because of the need I have now I can work in a chicken feed store, but if they are making me work more than 10 hours, they are abusing me, so that makes things more complicated". The employers' dynamic of demanding to work more hours than allowed is transversal in the study participants, who in their stories articulate that they have been victims of exploitation.

Immigrants point out that their employers know that they need the job, so they require them to work more hours than the legally established time. In this sense, it is known that it is difficult for immigrants to complain because they could lose their job, and with it, their visa subject to contract, so they would have to start their regularization again. An experience that captures the essence of this analysis is the words of Fernando, who commented: "[...] if you are a foreigner, some employers say: you do what I tell you to do, and if I ask you to work 12 hours, you have to do it. So, I feel that there is not much respect for the foreigner, I have to say it openly, to a certain extent, there is exploitation in jobs of this kind". The jobs referred to when they allude to the phrase "of this type" are those of low 
qualification for which higher education is not required. In this sense, immigrants perceive that after they are hired, more and more demands are placed on them, and the rules of the game are continuously changing, which is possible thanks to Chilean immigration policy.

Chilean legislation currently stipulates that the weekly workday must be 44 hours. However, loopholes in the current immigration regulations allow for abuse by employers towards immigrant workers, who depend on this contract to maintain their residency permit. These findings are similar to those of Blouin and Feline (2019), who found that Venezuelan immigrants in Lima (Perú) also have difficulty validating their degrees and are exploited with more hours than legal because they cannot access jobs in the area in which they were trained.

Following what was stated by several interviewees, discriminatory treatment is another aspect that has emerged in their labor incorporation. This reality is similar to that of Venezuelan immigrants in other South American countries, who suffer discrimination and mistreatment in poorly paid jobs (Zapata, Cuervo, 2019; Alfaro, Ramírez, 2019). The discourses indicate that the acts of discrimination are not constant, but they are violent, as Andrés points out: “...one that was super violent, super discriminating, told me to thank God that I had not been deported and all those things, do you understand me? There were even death threats that I made known to my superiors at the time, and they never took me seriously".

Several interviewees gave similar responses, who agreed that Chileans are aggressive when it comes to discriminating against them; despite this, the Venezuelans' reflections show that Chile is not a racist country and that discrimination is valid because it occurs in the work environment. When the interviewees were asked about the reason for this justification, they point out that they feel that this discrimination is not due to their phenotypical characteristics but to their condition as foreigners who are seen as a threat because they occupy the jobs of the Chilean population, as Jorge states: "[...]: on some occasions I have felt like a threat, like a foreigner who comes to occupy a job here and take jobs away from Chileans". It should be remarked that this issue appeared spontaneously in several interviews, where some people justified that this reality is strongly associated with the labor area and that they only feel that they are a threat in this area and, therefore, are recognized with this stigma, as Juan points out: "[...] being a foreigner, it is like a badge that you wear on your forehead, generally in labor situations where you are a foreigner, where you come to occupy a job, even though that job could be occupied by a Chilean".

In modern literature on prejudice and migration, the theoretical perspective of internalized threat posits that this comes from the stigma that immigrants have in society and that they perceive through their intergroup relations with the national population (Berríos-Riquelme et al., 2018). Following the theory, immigrants' internalized threat is a characteristic present in areas that have a high number of 
foreigners concerning the national population, such as the Tarapacá region, since intergroup relations confirm stereotypes that are not easy to avoid when the foreign collectivity is quite visible to nationals.

It is necessary to mention that although immigration has been socially constructed as a threat in Chile, this has occurred with greater force in the northern regions, mainly due to their historical past due to border disputes with their neighboring countries, which despite the decades that have passed, still live in the subconscious of the Chilean population living in the area (Carmona-Halty, Navas, Rojas-Paz, 2018; Munizaga, Díaz, 2005). For this reason, it is not surprising that Venezuelan immigrants in Tarapacá perceive this posture of Chileans towards them. In this way, the current Chilean migration legislation helps to construct foreigners as a threat. It does not allow the correct incorporation of professional immigrants, given that its regulations determine in advance the labor opportunities that these people will have in the country.

\section{Conclusion}

This article deals with the labor incorporation process of a group of professional Venezuelan immigrants in northern Chile. The participant's experience stands out for the difficulty to revalidate their university degrees, access to low-skilled jobs, and discrimination in the labor market, aspects that the current Chilean migration policy has determined.

In all of the participants, economic necessity dominated the criteria for decisions making, having to enter low-skilled jobs that do not relate to the area in which they were trained and which, according to them, meant a break in their life cycle. Their salaries are only enough for basic subsistence and not enough to start the procedures for revaluing their degree, describing this situation as momentary but stressful. Thus, after their migration, the participants have had downward professional mobility characterized by overqualification as a factor hindering their incorporation into the labor market. Although the results cannot be generalized, similarities were found with previous studies conducted with professional Venezuelan immigrants in another area of the country, suggesting that the situation of vulnerability could be transversal for this population in Chile.

Another finding, similar to previous studies, is labor discrimination and abuse. The participants point out that these facts are justified, given that they perceive that they are an economic threat to the national population for occupying their jobs. Regarding this issue, it is important to continue investigating since it has been proven that immigrants suffer harmful effects on their mental health when they perceive that they are discriminated against because they are seen as a threat in the workplace. For these reasons, the participants indicated that their incorporation into the labor market is stressful, but they are willing to overcome the obstacles to establish themselves and achieve an economic livelihood. 
Although the findings should be interpreted with caution due to their qualitative nature, the reports are consistent with the experiences of professional Venezuelan immigrants in Santiago de Chile and other cities in South America, leading to an analysis that these people prefer to insert themselves in a segmented market before returning to their country due to the current humanitarian crisis there. For this reason, it is imperative that the Government's policy not only focuses on the legal aspects of entry and control but should also be involved in promoting a receiving context that facilitates the integration of these people.

For future studies, it will be essential to consider the participation of immigrants who are not in a regularized situation, refugees, and immigrants who are not professionals; if this does not occur, we will have a biased view of Venezuelan's reality immigrants living in Chile. Another aspect will be to inquire about the variables that affect their mental health and psychosocial well-being, as well as to evaluate their impact in order to suggest intervention strategies for the agencies that work with this population, especially if we consider the reasons why they left their country and how difficult their incorporation into the receiving society has been. In this sense, it will also be important to inquire about these people's migratory project since it will allow us to know what would be the most feasible strategies to facilitate their social and labor insertion.

It is concluded that despite being qualified immigrants, the participants do not escape from the typical problems of the immigrant population in general, such as precarious jobs and discrimination. These issues are mostly due to the Chilean migration policy, which is the main hindering factor in their labor market insertion process. In this regard, it is possible to affirm that the current immigration law facilitates immigrants' labor precariousness in Chile and contributes to perpetuating the vulnerability of this population.

\section{References}

ALFARO, Yolanda; RAMÍREZ, Alejandra. "Arepas venezolanas a la orden": la presencia cada vez menos silenciosa de la migración venezolana en Cochabamba, Bolivia. In: GANDINI, Luciana; LOZANO, Fernando; PRIETO, Victoria (coords.). Crisis y migración de población venezolana. Entre la desprotección y la seguridad jurídica en Latinoamérica. Ciudad de México, México: Universidad Nacional Autónoma de México, 2019, p. 185-208.

BERRÍOS-RIQUELME, José; FRIAS-NAVARRO, Dolores; PASCUAL-SOLER, Marcos; BADENES-RIBERA, Laura. Escala de amenaza grupal internalizada por inmigrantes latinoamericanos en España: Evidencias iniciales de fiabilidad y validez. Interciencia, v. 43, n. 5, p. 365-371, 2018.

BLOUIN, Cécile Alice; FELINE, Luisa. Población venezolana en Lima: entre la regularización y la precariedad. In: GANDINI, Luciana; LOZANO, Fernando; PRIETO, Victoria (coords.). Crisis y migración de población venezolana. Entre la desprotección y la seguridad jurídica en Latinoamérica. Ciudad de México, México: Universidad Nacional Autónoma de México, 2019, p. 157-184. 
BUXTON, Julia. Venezuela: Deeper into the abyss. Revista de Ciencia Política, v. 38, n. 2, p. 409-428, 2018. Disponible en: <https://doi.org/10.4067/s0718090x2018000200409>.

BRYMAN, Alan. Social Research Methods. Oxford: Oxford University Press, 2012.

CASTLES, Stephen; HAAS, Hein; MILLER, Mark. The age of migration: International population movements in the modern world. New York, London: Guilford Press, 2014.

CARMONA-HALTY, Marcos; NAVAS, Marisol; ROJAS-PAZ, Paulina. Percepción de amenaza exogrupal, contacto intergrupal y prejuicio afectivo hacia colectivos migrantes latinoamericanos en Chile. Interciencia, v. 43, n. 1, p. 23-27, 2018.

Human Rights Watch. World Report 2020: Events of 2019. 2020. Disponible en: <https://www.hrw.org/sites/default/files/world_report_download/hrw_world_ report_2020_0.pdf>.

LEIVA, Sandra; MANSILLA, Miguel; COMELIN, Andrea. Condiciones laborales de migrantes bolivianas que realizan trabajo de cuidado en Iquique. Si Somos Americanos, v. 17, n. 1, p. 11-37, 2017. Disponible en: < https://doi.org/10.4067/ S0719-09482017000100011>.

MUNIZAGA, Claudio; DíAZ, Alberto. Monumentos, fiestas y desfiles en Iquique. Nacionalismo en 1900, patrimonio en el 2000. Si Somos Americanos, v. 7, n. 2, p. 139-153, 2005.

Organización para la Cooperación y el Desarrollo Económico. International Migration Outlook 2019. París, Francia: OECD Publishing, 2019. DOI: https://doi.org/10.1787/ c3e35eec-en.

Organización Internacional para las Migraciones. Informe sobre las migraciones en el mundo 2020. Ginebra, Suiza: OIM, 2019.

PAVEZ-SOTO, Iskra; COLOMÉS, Sofía. Derechos humanos y política migratoria. Discriminación arbitraria en el control de fronteras en Chile. Polis, v. 51, p. 113136, 2018. DOI: https://doi.org/10.32735/S0718-6568/2018-N51-1352.

PITTALUGA, Giovanni; SEGHEZZA, Elena; MORELLI, Pierluigi. The political economy of hyperinflation in Venezuela. Public Choice, v. 186, p. 337-350, 2020. DOI: https://doi.org/10.1007/s11127-019-00766-5.

PORTES, Alejandro. Migration, Development, and Segmented Assimilation: A Conceptual Review of the Evidence. The Annals of the American Academy of Political and Social Sciences, v. 610, n. 1, p. 73-97, 2007. Disponible en: <https:// doi.org/10.1177/0002716206296779>.

RAMÍREZ, Jacques; LINARES, Yoharlis; USECHE, Emilio. (Geo)Políticas migratorias, inserción laboral y xenofobia: migrantes venezolanos en Ecuador. In: BLOUIN, Cécile (coord.). Después de la llegada. Realidades de la migración venezolana. Lima, Perú: Themis-PUCP, 2019.

ROJAS, C. Crisis humanitaria de venezolanos en la frontera norte de Chile en 2019: Análisis de la actuación del Estado frente a la gestión del Refugio. Trabajo fin de Máster. España: Universidad Autónoma de Madrid, 2019. 
STEFONI, Carolina. Ley y política migratoria en Chile. La ambivalencia en la comprensión del migrante. In: FELDMAN-BIANCO, Bela; RIVERA SÁNCHEZ, Liliana; STEFONI, Carolina; VILLA MARTÍNEZ, Marta Inés (comps.). La construcción social del sujeto migrante en América Latina. Prácticas representaciones y categorías. Santiago, Chile: CLACSO-FLACSO-Universidad Alberto Hurtado, 2011, p. 79-109.

STEFONI, Carolina; GUIZARDI, Menara; GONZÁLVEZ, Herminia. La construcción política de la frontera. Entre los discursos nacionalistas y la "producción" de trabajadores precarios. Polis, v. 51, p. 137-162, 2018. Disponible en: < http://doi. org/10.32735/S0718-6568/2018-N51-1353>.

STEFONI, Carolina; SILVA, Claudia; BRITO, Sebastian. Migración venezolana en Chile. La (des)esperanza de los jóvenes. In: GANDINI, Luciana; LOZANO, Fernando; PRIETO, Victoria (coords.). Crisis y migración de población venezolana. Entre la desprotección y la seguridad jurídica en Latinoamérica. Ciudad de México, México: Universidad Nacional Autónoma de México, 2019, p. 259-284.

TAPIA, Marcela. Frontera, movilidad y circulación reciente de peruanos y bolivianos en el norte de Chile. Estudios Atacameños, v. 50, 195-213, 2015. Disponible en: $<$ http://doi.org/10.4067/S0718-10432015000100010>.

TAPIA, Marcela: RAMOS, Romina. Mujeres migrantes fronterizas en Tarapacá a principios del siglo XXI. El cruce de las fronteras y las redes de apoyo. Polis, v. 12, n. 35, p. 229-257, 2013. Disponible en: <https://doi.org/10.4067/S0718$65682013000200011>$.

THAYER, Luís Eduardo. Migración, Estado y Seguridad. Tensiones no resueltas y paradojas persistentes. Polis, v. 15, n. 44, p. 109-129, 2016.

URZÚA, Alfonso; BOUDON, Susana; CAQUEO-URÍZAR, Aleandra. Salud mental y estrategias de aculturación en inmigrantes colombianos y peruanos en el norte de Chile. Acta Colombiana de Psicología, v. 20, n. 1, p. 70-79, 2017. Disponible en: $<$ https://doi.org/10.14718/ACP.2017.20.1.5>.

ZAPATA, Gisela P.; CUERVO, Selma Marcela. De la frontera a la metrópolis: la experiencia migratoria de venezolanos en Brasil. In: GANDINI, Luciana; LOZANO, Fernando; PRIETO, Victoria (coords.). Crisis y migración de población venezolana. Entre la desprotección y la seguridad jurídica en Latinoamérica. Ciudad de México, México: Universidad Nacional Autónoma de México, 2019, p. 95-124. 